\title{
Is cloning an attack on human dignity?
}

Sir - Appeals to human dignity, and to the moral obligation to protect it, have been a feature of responses to the cloning of Dolly the sheep (Nature 385, 810-813; 1997). Dr Hiroshi Nakajima, director general of the World Health Organization (WHO), said: "WHO considers the use of cloning for the replication of human individuals to be ethically unacceptable as it would violate some of the basic principles which govern medically assisted procreation. These include respect for the dignity of the human being."

The European Parliament rushed through a resolution banning cloning, which stated as part of the rationale (clause 6) that the parliament "believes it is essential to establish ethical standards, based on respect for human dignity, in the areas of biology, biotechnology and medicine". Neither of these august authorities provided a scrap of argument as to how the idea of human dignity is relevant to the ethics of cloning.

A first question to ask when the idea of human dignity is invoked is: whose dignity is attacked and how? Is it the duplication of a large part of the genome that is supposed to constitute the attack on human dignity? If so, we might legitimately ask whether and how the dignity of a natural twin is threatened by the existence of the other twin. The notion of human dignity is often also linked to Kantian ethics. A typical example, and one that attempts to provide some basis for objections to cloning based on human dignity, is Axel Kahn's invocation of this principle in his Commentary on cloning (Nature 386, 119; 1997).

But the Kantian principle, which is generally interpreted as demanding that "an individual should never be thought of as a means but always also as an end", crudely invoked, as it usually is, without any qualification or gloss, is seldom helpful in a medical or bioscience context. It would outlaw blood transfusions and abortions carried out to protect the life or health of the mother. It would also outlaw one form of cloning, embryo splitting, which could allow genetic and other screening by embryo biopsy. One embryo could be tested to ascertain the health and genetic status of the remaining clones, and then destroyed. To this it is objected, pace Kahn, that one twin would be destroyed for the sake of another.

It is bizarre and misleading to marshal the Kantian principle as an objection either to using cell mass division to create clones for screening purposes, or to creating clones by nuclear substitution to generate spare cell lines. It is surely ethically dubious to object to one embryo being killed for the sake of another, but not to object to it being killed for nothing. In in vitro fertilization (IVF), for example, it is, in the United Kingdom, regarded as good practice to store spare embryos for future use by the mother or for disposal at her direction, either to other women who require donor eggs, or for research, or simply to be destroyed. It cannot be morally worse to use an embryo to provide information about its sibling than to use it for more abstract research or simply to destroy it. If it is permissible to use early embryos for research or to destroy them, their use in genetic and other health testing is surely also permissible. The same would surely go for their use in creating cell lines for therapeutic purposes.

A moral principle that has at least as much intuitive force as that recommended by Kant is that it is better to do some good than to do no good. It cannot, from the ethical point of view, be better or more moral to waste human material that could be used for therapeutic purposes than to use it to do good. If it is right to use embryos for research or therapy then it is surely also right to produce them for such purposes, as is usual in IVF. Kant's prohibition does after all refer principally to use. Of course some will think that the embryo is a full member of the moral community with all the rights and protections possessed by Kant himself. Although this is a tenable position, it cannot consistently be held by any society that permits abortion, post-coital contraception or research with human embryos.

\section{John Harris}

Centre for Social Ethics and Policy,

University of Manchester,

Manchester M13 9PL, UK

e-mail:Rebecca.Bennett@man.ac.uk

\section{Protect patients' rights}

Sir - Those of us who are concerned about the increasing incidence of biomedical discrimination and violations of medical privacy appreciate your attention to these issues (Nature 386, 533; 1997). We need, however, to deal directly with the fact that research scientists do not have an exemplary track record.

For example, recent media coverage of the Tuskegee experiment (see Nature 387, $116 ; 1997)$ serves as a reminder of why the United States had to develop the institution of Human Subjects Review Boards. Abuses of the rights of patients have contributed to the increased development of notions of appropriate informed consent.

In this regard, I believe your coverage has put too much emphasis on the needs of research scientists, while underplaying the integrity and dignity of research subjects. For example, as the increasing number of state legislative enactments protecting genetic information indicates, the donor or source of the material must have control over the sample and any access to it. As far as protecting the rights of the donor is concerned, it is immaterial whether the third party seeking access to the sample is wearing a lab coat or not.

Philip L. Bereano

(Chair, American Civil Liberties Committee on Data Access, Storage, and Dissemination)

Department of Technical Communication, University of Washington,

Box 352195, Seattle,

Washington 98195-2195, USA

\section{Hubble 'worth the price'}

Sir - David Leverington claims to be measuring cost-effectiveness of astronomical observations, and your provocative headline, "Star-gazing funds should come down to Earth," shows that his conclusion can lead to important consequences (Nature 387, 12; 1997). But, as his Correspondence shows, he is really merely measuring the number of times various papers have been cited.
He has no way of accounting for the uniqueness of an observation or considering the changes in our understanding that can result from breakthrough discoveries. His reliance on citation is like poll-driven government: it has some value but isn't necessarily the best.

In particular, he says that, "although the Hubble Space Telescope has been extremely successful, Figure 1 shows that it has not yet justified its high costs...". I submit that this conclusion is ridiculous and that, after seeing the wealth of unique and revealing observations that have been and are still pouring from Hubble, an observational scientist is driven to finding out what is wrong with Leverington's arguments rather than accepting his conclusion. After all, if we assign a factor of 3 for uniqueness, then the space observations would meet even his absurd criteria.

Jay M. Pasachoff

Hopkins Observatory,

Williams College,

Williamstown, Massachusetts 01267, USA

e-mail: jay.m.pasachoff@williams.edu 